\title{
Forest Policy Developments Développement de politique forestière
}

\section{Canadian Paperworkers' Union Forest Policy Statement}

The policy statement below was adopted by the Canadian Papermakers' Union (CPU) at its 6th Convention in Saint John, N.B., in September 1986. It is a well researched and clearly presented statement, and is reproduced here with CPU's permission. Editor.

Forestry supports the single most important industrial sector in the Canadian economy. Some 300000 jobs are generated directly by forest sector industries and twice as many indirectly as there are large scale benefits in sectors such as transportation, construction, machinery and service industries. The employment impact spreads from the rural forest areas into basic manufacturing and into every metropolitan area of Canada.

The CPU members' stake in the forest economy rests squarely on job opportunity. The connection between growing resource scarcity and the threat to industrial payrolls is only too obvious. Neglect of the forest leads to unemployment, social decay and dislocation with all the attendant costs. This, of course, reflects our dependance on its use. In contrast, proper stewardship of the resource base can help to ensure regional economic vitality and stable growth in both employment and income.

Mismanagement of the forest resource base can only have a negative impact on the entire economy of Canada. It may also result in a degradation and a reduction in the life style of us all. At stake here is the supply of high quality water, the habitat for fish and wildlife, and the recreation base for millions. In this broader sense, then, the CPU's interest in forestry embraces the entire community of Canadians, in this generation and in succeeding ones.

The need for CPU Policy Statement is based on a conviction that forest management policies have been neglected in every region of Canada, and in the fact that nontimber values are now colliding everywhere with traditional industrial use.

The result is that new perceptions of forest land use have forced industry as well as governments to revise their attitudes and commitment toward forest resource management. As a matter of principle, and because of the slow pace of improvement in overall forest management performance, the trade union movement should become an active participant in policy formulation and subsequent program assessment. Federal/provincial agreements in recent years represent a move toward forest improvement.

The entire range of policies which impact on forest resource management and use are of interest to all CPU members as they should be to all citizens of our country.

The CPU believes that workers and other citizens of forest-based communities must offer alternatives to the present forestry agenda. Many experienced forest observers doubt whether current reforestation strategies will actually succeed in providing a healthy, productive second forest. With this in mind, we put forward the following Forestry Policy.

\section{Policy}

The CPU subscribes to the concept of multiple use of forest land while maintaining that an overall strategy and proper planning is required to make the forest sector healthy and in a position to benefit from the economic opportunities of the future. This multiple vocation of the forest takes account of important values which should be considered as complementary rather than in competition with one another and nor should it preclude the withdrawal of defined land areas for single use purpose.

\section{Forest Inventories}

- Provinces should be required by law to maintain continuous forest inventories which are conducted on a cycle of more than 10 years.

- These inventories should include volume, age, species, site class, tree form and other information sufficient to provide growth and yield projections, production goal planning, and forest renewal strategies for each forest management unit in the entire provincial area.

- The inventory data base must therefore include private land forests, in order to ensure aggregation to provincial totals by sub-region.

- A Forest Auditor's Office should be created in each province, much like the Auditor-General who monitors public finances. We need to audit the public forests. Since so much government money is to be spent on forestry over the next few years, we must ensure that it is well spent.

The provincial Forest Auditor should have an adequate budget and staff and be totally independent of resource ministries, local operating authorities and wood-using industries. The Forest Auditor should inspect and monitor all reforestation efforts on public and private lands, reporting results annually. The auditor's office could be a source of employment for some of the many professional foresters and forest technicians who now face uncertain employment futures.

\section{Forest Renewal Measures}

- The basic minimum of forestry should be prompt regeneration of cutover lands, using natural regeneration wherever practical and planting where sites are not expected to regenerate adequately on their own. Maximum reliance should be placed on superior seedings in artificial regeneration. The amount of planting should be determined from the production goals as set in inventory reports.

- Some priority must be given to finding new methods for improving natural seeding and stocking.

- Weeding and brushing are an integral part of forest renewal, to ensure that the new crop, whether natural or planted, is not choked out by competing vegetation. 
- The objective is to get the new plantation to the stage called "free to grow".

- A regular follow-up program should include juvenile spacing, conifer release, pre-commercial thinning and possibly fertilization as these may be required to meet the production goals.

The goal of this forest policy is to put as many local people to work in the forest and at the same time to develop as much local forestry expertise as possible. We should be creating a skilled forestry workforce over the long term. We need such a workforce if the forest is to support our jobs in the long term.

\section{Rehabilitation of Backlog}

- The NSR or "not satisfactorily restocked" lands should be placed in production, with first priority given to those sites close to processing plants.

- Factors to be considered for placing land back in production are the perspective of reasonable harvesting costs and the prevention of economic decline resulting from diminishing supply of the resource.

\section{Small Woodlots}

- Higher priority must be given to non-industrial private timber lands, given their essential role in providing fibre supplies in several provinces. This means supplementing industrial logging in order to achieve higher forest production levels consistent with the long-term forest policy objectives.

- Programs should include education and extension, revision of income and property taxes, and cooperative systems for renewal and marketing.

- The objective of providing assistance to small landowners is to stabilize rural income and to improve the wood supply situation in the long term, thus preventing shortages from developing in the pulp-paper and wood industries.

\section{Forest Renewal Costs}

- Those who benefit should pay for forest renewal and the two senior levels of governments and industry obviously benefit the most. Thus, a fair share of the tax revenue from forest-related activities should be allocated to maintaining and improving the resource base. This is a sound principle which was endorsed by consensus at the Banff Forestry Conference in 1981.

- The funding formula should be related to the responsibility shouldered for forest renewal and so there must be a clear destination in terms of incentives between licence holders who renew the forest at their own expenses and short-term permit holders who do not.

- Long-term licences should be granted only if and when the conditions for forest renewal and environmental management objectives are absolutely clear, and when performance audits are satisfactory.

\section{Harvesting}

- Methods used in harvesting must ensure the cutover land is left in optimum condition for regeneration.
- Harvesting and road building must also be conducted in a manner to minimize ecological damage.

\section{Non-Timber Values}

- Recognition of the recreation, wilderness, wildlife, watershed and other non-timber values must be evidenced in the strategic goals as well as in the shorter term working plans of land managers.

\section{Planning}

- A minimum 20-year timber supply strategy should be required before joint federal-provincial forestry agreements are signed, such strategies to include forest renewal, utilization and protection programs.

- In addition, provinces should have 5-year forest renewal plans for each forest management unit, to be updated annually.

- Provincial forest ministries should also be required by law to provide their respective legislatures with forest resource status report at 5-year intervals, including growth goal targets and related performance.

- Licensees should also be required to report to a forestry standing committee their timber supply strategy and performance at regular intervals.

- The above planning should be fully integrated, or multipleuse in scope, covering non-timber as well as industrial timber values.

\section{Protection}

- The necessity for protecting the forests against fire, insects and disease should be self-evident as more tax revenues are being committed to reforestation and intensive forestry to augment wood supply and enhance land productivity for that purpose.

- Forest fire losses have been excessive over the past decade and a new strategy must be developed to reduce the damage, especially on productive forest lands near the producing mills.

- Insect losses have been even more costly, given the fact that insects tend to attack mature timber which is the most valuable and is often scheduled for harvest in the next decade.

- Greater efforts must be made to develop non-chemical sprays, synthetic pheromones and other alternative methods of insect control.

- Provincial governments have the prime responsibility for insect control programs based on public health department findings and for making systematic evaluations of their effectiveness.

- CPU members play a dual role, as workers in an industry whose resource is affected by insects and disease and as citizens with health and environmental concerns. They share the conviction that protection programs cannot be separated from comprehensive and effective forest management policies under the overall control of governments. 


\section{Research and Governments}

- Continued vigilance should be exercised over acid rain impacts on Canadian forests. In particuilar, Canadian governments should increase research on acid rain and pursue their efforts toward formal agreements with the United States' authorities on reducing its ravages and making the forests clean.

- The status of forestry science in Canada is lagging behind competing regions and this must be corrected by building research capability and by assessing research relevance for early application to silviculture, as compared to protection, and in other respects.

- The federal government is the recipient of the major share of the tax revenue from the forest sector and the larger is the tax revenue when the sector is healthy. Federal funding for forest renewal should be commensurate with its share of forest tax revenue.

- A full separate federal Department of Forestry is called for, together with a separate Standing Committee on Forestry.

- A selective, sample audit of field forestry performance is needed to ensure accountability on the part of land managers, whether senior governments or industry. Objective standards of performance should be laid down in advance for renewal, protection and utilization.

\section{Manpower}

- In view of the job potential in forestry and particularly in forest renewal activities, which are labour intensive, labour and manpower departments should make periodic projections of the demand and supply for labour with accurate assessments of shortages and surpluses, develop programs for occupational training, and consider appropriate measures to ensure equitable access to job opportunities for women, young people and other groups.

- Subcontracting, hiring practices, employee turnover, safety training and working conditions should be examined in depth by the appropriate government departments with a view to achieving the goal of a stable, qualified and wellremunerated labour force in forestry.

- Silvicultural and other occupations in forestry should be clearly listed in the Canadian Classification and Dictionary of Occupations (CCDO) as the absence of such information constitutes an impediment to design and development of training courses.

\section{Letters/Lettres}

\section{Gold Medal Winner Thanks CIF}

Dear Dr. Bourchier:

I wish to thank the Canadian Institute of Forestry for awarding me the CIF Medal as a graduate of the University of Alberta Forestry Class of 1987 . I would also like to extend my congratulations to the other CIF Medal winners across Canada, particularly Cindy Fox at the University of British Columbia. Before attending university, I worked with Cindy in Merritt, B.C.

After graduation, I took a position as Forestry Supervisor with Balco Division of Tolko Industries in Kamloops, B.C. Although I have an NSERC Scholarship, I will postpone further formal education in favor of industry experience. At some point, I intend to pursue either a Master of Science Degree in Forest Ecology, or an MBA.

While at the $U$ of $A, I$ was able to attend several meetings of the Rocky Mountain Section of the CIF and one Alberta Forestry Association meeting. All were worthwhile, but I especially enjoyed those that featured a panel discussion. The enthusiasm of the Rocky Mountain Section members is infectious, and I have every intention of becoming more involved with the CIF and the CFA in B.C. now that I have settled into a full-time job.

Again, thank you for honoring me with the CIF Medal. I can assure you that I will endeavor to maintain the standard I established at university as I begin a career in the forest industry.

Sincerely,

Kim Young, BSc.
May, 1987

The Editor

\section{Re: African Forestry and Environmental Recovery}

I am writing to inform you that we are a newly-formed forestry association primarily concerned with community (social) forestry and environmental issues in Africa. A Mission Statement outlining the aims and objectives of our association is enclosed. We feel we can play a vital role in trying to address the forestry and environmental problems that Africa faces today. Currently only about $4 \%$ of the African land base can be classified as under forest cover. This figure was as high as $45 \%$ a century ago.

We will be embarking soon on a major fund raising drive for African forestry recovery. Our association has the backing of labour, forestry professionals, industry, community groups, non-governmental organizations and student bodies. We are very much interested in:

a) the development of interest and expertise in social forestry amongst the forest community in B.C. and across Canada;

b) compilation of reference list of B.C./Canada foestry/ environmental specialists having Third World experience or interested in working in the Third World;

c) assistance in fund raising activities from other organizations; and

d) recruitment of members, either as groups or individuals, from all professions to become actively involved in our association. 